\title{
Character Association and Path Analysis of Grain Yield and its Components in Maize (Zea mays L.) under Heat Stress
}

\author{
Asit Prasad Dash ${ }^{1 *}$, D. Lenka ${ }^{1}$, S. K. Tripathy ${ }^{2}$, D. Swain ${ }^{3}$ and Devidutta Lenka ${ }^{1}$ \\ ${ }^{1}$ Department of Plant Breeding and Genetics, College of Agriculture, \\ OUAT, Bhubaneswar, Odisha, India \\ ${ }^{2}$ Department of Agricultural Biotechnology, College of Agriculture, \\ OUAT, Bhubaneswar, Odisha, India \\ ${ }^{3}$ OIC, AICRP (Maize), College of Agriculture, OUAT, Bhubaneswar, Odisha, India \\ *Corresponding author
}

\section{Keywords \\ Maize, correlation, path analysis, grain yield and heat stress \\ Article Info \\ Accepted: \\ 22 February 2020 \\ Available Online: \\ 10 March 2020}

\section{A B S T R A C T}

Maize (Zea mays L.) is one of the most diversified and versatile crop grown worldwide under varied agro-climatic condition. However, a significant amount of reduction in grain yield has been reported because of heat stress. Being a complicated character that depends on multiple component traits, direct selection is in effective for grain yield. Considering these aspects, a study was conducted to determine the magnitude and extent of trait interdependency among yield and yield attributing characters under heat stress condition using forty five maize hybrids. The hybrids were evaluated by following randomized block design with two replications at EB-II section of the Department of Plant Breeding and Genetics, College of Agriculture, OUAT, Bhubaneswar during Summer 2018. Association studies revealed that, six characters viz., plant height, ear height, cob diameter, number of grain rows per cob, number of grains per row and 100 seed weight exhibited significantly positive correlation at both genotypic and phenotypic level, while anthesis to silking interval was the only trait that attained negative significant correlation at genotypic level with grain yield per plant. Path analysis indicated that plant height, ear height, number of rows per cob and 100 grain weight have positive direct effect while, anthesis to silking interval has negative direct effect on grain yield per plant. Hence, these traits in desirable direction could be relied upon for selection of genotypes in order to improve genetic yield potential of maize under heat stress condition.

\section{Introduction}

Globally, maize (Zea mays L.) is the third most important cereal crop, which is cultivated on nearly 197.19 million hectare of land with wider diversity of soil, climate, biodiversity and management practices with production of 1134.75 million tonnes and productivity of 5.76 tonnes per hectare (FAOSTAT, 2017). India is the sixth largest producer and the fifth largest consumer of maize in the world, grown on an area of 9.22 million hectare with production of 28.72 million tonnes and productivity of 3.12 tonnes 
per hectare (FAOSTAT, 2017). It is one of the most widely distributed crops and its expansion to new areas and environment still continuesowing to its adaptability to diverse environmental condition.

Forecasts indicate that by the year 2050, the demand for maize in the developing countries will double (Rosegrant et al., 2009 and Prasanna 2014) owing to the newly emerging food habits, livestock products as well as enhanced industrial requirements of rapidly expanding human population. Thus, in order to meet this demand, intensification of cropping system and increased productivity is the only way. However, this goal of increasing maize production and productivity has been hindered by the global climate change that includes rising temperatures, frequent heat waves, drought, floods, desertification and weather extremes (IPCC, 2009).A record drop in maize production due to heat waves has already been reported globally (Ciais et al., 2005; Van der Velde et $a l ., 2010)$.It has been anticipated that growing season temperature in the tropics and subtropics will exceed even the most extreme seasonal temperatures so far, while in temperate regions, the hottest seasons on record will become the normal temperature (Battisti and Naylor, 2009). Thus a huge loss in corn production can be expected in the near future. Hence, development of heat stress tolerant maize germplasm is the need of the hour.

Selection based on grain yield is quite not reliable as yield is a complex quantitative trait that is governed by poly genes and also highly influenced by environmental factors in which the crop is grown. So selection of secondary traits associated with this complex trait is a way to achieve higher grain yield. Correlation analysis used as effective tool to determine the relationship among different traits in genetic diverse population for enhancement of crop improvement process. As more variables are included in the correlation study, the associations become more complex. In such a situation, the path coefficient analysis provides an effective means of finding out direct and indirect causes and effects of association and permits a critical examination of the specific forces acting to produce a given correlation and measures the relative importance of each factor. Thus aim of this study was to find out potential secondary traits associated with grain yield under heat stress condition in maize hybrids through correlation and path analysis.

\section{Materials and Methods}

\section{Experimental details}

The experimental material for the present study comprised of forty five maize $\mathrm{F}_{1}$ s(Table 1) generated by crossing previously identified 15 heat tolerant double haploid lines with 3 double haploid testers collected from International Maize and Wheat Improvement Center (CIMMYT), Hyderabad, India. The $\mathrm{F}_{1} \mathrm{~s}$ were evaluated in a randomized block design with two replications during spring, 2018 at EB-II section of the Department of Plant Breeding and Genetics, College of Agriculture, OUAT, Bhubaneswar. Each entry was sown in two rows of 4 meter length spaced at $60 \mathrm{~cm}$ with a plant to plant spacing of $30 \mathrm{~cm}$. Two seeds per hill were sown followed by thinning to maintain single plant per hill. In order to avoid the influence of moisture stress on the plants, proper care was taken by mulching the soil with paddy straw along with need based irrigation. Fertilizers were applied at the rate of $120 \mathrm{~kg} \mathrm{~N}, 60 \mathrm{~kg}$ $\mathrm{P}_{2} \mathrm{O}_{5}$ and $60 \mathrm{~kg} \mathrm{~K} 2 \mathrm{O}$ per hectare in the form of Urea, SSP and MOP respectively along with FYM 12 cart loads/ha and Zinc Sulphate $25 \mathrm{~kg} / \mathrm{ha}$. Normal agronomic practices and plant protection measures were followed to raise a successful crop. 
The flowering occurred during the month of May, wherein the maximum and minimum temperature ranged between $35-39^{\circ} \mathrm{C}$ and 20 $28^{\circ} \mathrm{C}$ respectively, while the mean relative humidity during the flowering period was $74 \%$.Data was recorded on five randomly selected plants from each $\mathrm{F}_{1} \mathrm{~s}$ for twelve traits viz., days to $50 \%$ tasseling (DT), days to $50 \%$ silking (DS), anthesis to silking interval (ASI), days to $75 \%$ dry husk (DDH), plant height (PH), ear height (EH), cob length (CL), cob diameter (CD), number of grain rows per cob $(\mathrm{R} / \mathrm{C})$, Number of grains per row $(\mathrm{G} / \mathrm{R})$, 100 seed weight (SW) and grain yield per plant $(\mathrm{GY} / \mathrm{P})$.The data was analyzed for estimating the correlation coefficients as described by Snedecor and Cochran, (1965) and path co-efficient analysis was carried out at the genotypic level by taking grain yield per plant as dependent variable against other measured traits as independent variables as suggested by Wright (1921) and discussed by Dewey and Lu (1959).

\section{Results and Discussion}

The phenotypic, genotypic correlation and path coefficients of twelve agro-economic traits of forty five maize hybrids were depicted in table 2 and table 3 respectively. The correlation coefficients were found to be significant at both genotypic and phenotypic level for most of the character combinations. In majority of the cases, genotypic correlation coefficient was higher than phenotypic correlation coefficients. Grain yield per plant was observed to have significant positive genotypic and phenotypic correlation with plant height (0.642 \&0.558), ear height $(0.451$ $\&$ 0.395), cob diameter (0.620 \& 0.574), number of grain rows per cob $(0.254 \&$ $0.272)$, number of grains per row $(0.686 \&$ $0.701)$ and 100 seed weight(0.469 \& 0.459$)$. All these component traits except number of grain rows per cob at genotypic level recorded significant genotypic and phenotypic correlation coefficient at even $1 \%$ level of significance. A negative significant genotypic correlation (-0.305) was observed between anthesis to silking interval and grain yield per plant. Four characters viz., days to $50 \%$ tasseling, days to $50 \%$ silking, days to $75 \%$ dry husk and plant height exhibited nonsignificant negative correlation coefficient with grain yield per plant at both genotypic and phenotypic level.

Perusal of table 3 showed a residual effect of 0.028 from the path analysis. The analysis revealed that five out of eleven traits had positive direct effect on grain yield. The highest direct effect on grain yield was exhibited by days to $50 \%$ silking (3.309) followed by plant height (0.647), number of grain rows per cob (0.634) and 100 seed weight (0.318).However, days to $50 \%$ tasselling had the largest negative direct effect on grain yield per plant(-3.684) followed by anthesis to sillking interval (-1.027) and cob length (-0.247). In general days to $50 \%$ tasseling was found to have negative indirect effect, whereas days to $50 \%$ silking was found to have positive indirect effect on grain yield per plant through other component characters.

Character association is a helping hand to study the interdependence among traits and quite useful to chalk out the component traits in connection with the target descriptor i.e. grain yield per plant. The genotypic and phenotypic correlations among the traits studied pointed out the existence of statistically significant relationships among them. The higher value of genotypic correlation coefficients than that of phenotypic correlation coefficients for most of the character combinations indicated the strong inherent association between the characters, which is largely governed by genetic causes and less affected by the environment. Such findings are in close 
conformity with the results of Ghosh et al., (2014) and Alake et al., (2008). The component traits; plant height, ear height, cob diameter, number of grain rows per cob, number of grains per row and 100 seed weight displaying positive and significant association with grain yield per plant suggested that grain yield can be improved through simultaneous selection for these traits. These associations are partly in accordance with the earlier results observed by Jodage et al., (2017), Al-Tabbal and AlFraihat (2012), Rani et al., (2017), Ghosh et al., (2014), Rafiq et al., (2010) and Wali et al., (2012),Seyedzavar et al., (2015), Palta et al., (2011); Khazaei et al., (2010), Alvi et al., (2003), Najeeb et al., (2009) and Nemati et al., (2009). Anthesis to silking interval was the only character that exhibited significant negative association with grain yield per plant suggesting that the genotypes with less gap between anthesis and silking will give higher grain yield per plant under heat stress condition. Magorokosho et al., (2003) reported that selection for genotypes with reduced ASI was more effective than grain yield alone under drought stress. Days to 50\% tasselling, days to $50 \%$ silking and days to $75 \%$ dry husk were positively correlated with each other whereas each one of them exhibited a non-significant negative correlation with yield per plant indicating the reverse relationship among the maturity related traits and grain yield per plant.

Table.1 Forty five hybrids generated from crossing programme

\begin{tabular}{|c|c|c|c|c|c|}
\hline $\mathbf{1}$ & ZL155069 × ZL155828 & 16 & ZL155132 $\times$ ZL155828 & 31 & ZL155201 $\times$ ZL155828 \\
\hline 2 & ZL155069 × ZL154230 & 17 & ZL155132 × ZL154230 & 32 & ZL155201 × ZL154230 \\
\hline 3 & ZL155069 × CML 451 & 18 & ZL155132 × CML 451 & 33 & ZL155201 × CML 451 \\
\hline 4 & ZL155085 × ZL155828 & 19 & ZL155136 × ZL155828 & 34 & ZL155219 × ZL155828 \\
\hline 5 & ZL155085 × ZL154230 & 20 & ZL155136 × ZL154230 & 35 & ZL155219 × ZL154230 \\
\hline 6 & ZL155085 × CML 451 & 21 & ZL155136 × CML 451 & 36 & ZL155219 $\times$ CML 451 \\
\hline 7 & ZL155110 × ZL155828 & 22 & ZL155181 × ZL155828 & 37 & ZL155235 × ZL155828 \\
\hline 8 & ZL155110 × ZL154230 & 23 & ZL155181 × ZL154230 & 38 & ZL155235 × ZL154230 \\
\hline 9 & ZL155110 × CML 451 & 24 & ZL155181 × CML451 & 39 & ZL155235 × CML451 \\
\hline 10 & ZL155115 × ZL155828 & 25 & ZL155187 × ZL155828 & 40 & ZL155246 × ZL155828 \\
\hline 11 & ZL155115 × ZL154230 & 26 & ZL155187 × ZL154230 & 41 & ZL155246 × ZL154230 \\
\hline 12 & ZL155115 × CML 451 & 27 & ZL155187 × CML 451 & 42 & ZL155246 × CML 451 \\
\hline 13 & ZL155122 × ZL155828 & 28 & ZL155199 × ZL155828 & 43 & ZL155247 × ZL155828 \\
\hline 14 & ZL155122 × ZL154230 & 29 & ZL155199 × ZL154230 & 44 & ZL155247 × ZL154230 \\
\hline 15 & ZL155122 × CML 451 & 30 & ZL155199 × CML 451 & 45 & ZL155247 × CML 451 \\
\hline
\end{tabular}


Table.2 Phenotypic $\left(r_{p}\right)$ and genotypic $\left(r_{g}\right)$ correlation coefficients among twelve agro-economic traits of 45 maize hybrids

\begin{tabular}{|c|c|c|c|c|c|c|c|c|c|c|c|c|}
\hline Characters & $\begin{array}{c}\text { Correlation } \\
\text { coefficient }\end{array}$ & $\begin{array}{c}\text { Days to } \\
50 \% \\
\text { tasselling }\end{array}$ & $\begin{array}{c}\text { Days to } \\
\mathbf{5 0 \%} \\
\text { silking }\end{array}$ & ASI & $\begin{array}{c}\text { Days to } \\
\mathbf{7 5 \%} \\
\text { dry } \\
\text { husk }\end{array}$ & $\begin{array}{c}\text { Plant } \\
\text { height } \\
(\mathbf{c m})\end{array}$ & $\begin{array}{c}\text { Ear } \\
\text { height } \\
(\mathrm{cm})\end{array}$ & $\begin{array}{c}\text { Cob } \\
\text { length } \\
(\mathrm{cm})\end{array}$ & $\begin{array}{c}\text { Cob } \\
\text { dia- } \\
\text { meter } \\
(\mathrm{cm})\end{array}$ & $\begin{array}{l}\text { No. of } \\
\text { grain } \\
\text { rows/ } \\
\text { cob }\end{array}$ & $\begin{array}{c}\text { No. of } \\
\text { grains/row }\end{array}$ & $\begin{array}{l}\text { 100- Seed } \\
\text { weight } \\
\text { (g) }\end{array}$ \\
\hline \multirow{2}{*}{$\begin{array}{c}\text { Days to } 50 \% \\
\text { silking }\end{array}$} & $r_{g}$ & $0.991 * *$ & & & & & & & & & & \\
\hline & $r_{p}$ & $0.942 * *$ & & & & & & & & & & \\
\hline \multirow[t]{2}{*}{ ASI } & $r_{g}$ & $-0.236^{*}$ & -0.104 & & & & & & & & & \\
\hline & $r_{p}$ & -0.168 & 0.172 & & & & & & & & & \\
\hline \multirow{2}{*}{$\begin{array}{c}\text { Days to } 75 \% \\
\text { dry husk }\end{array}$} & $r_{g}$ & $0.703 * *$ & $0.691 * *$ & -0.202 & & & & & & & & \\
\hline & $r_{p}$ & $0.691 * *$ & $0.708 * *$ & 0.052 & & & & & & & & \\
\hline \multirow{2}{*}{$\begin{array}{c}\text { Plant height } \\
\text { (cm) }\end{array}$} & $r_{g}$ & $0.513 * *$ & $0.518 * *$ & -0.054 & $0.255^{*}$ & & & & & & & \\
\hline & $r_{p}$ & $0.444 * *$ & $0.464 * *$ & 0.060 & $0.235^{*}$ & & & & & & & \\
\hline \multirow{2}{*}{$\begin{array}{c}\text { Ear height } \\
\quad(\mathrm{cm})\end{array}$} & $r_{g}$ & $0.639 * *$ & $0.624 * *$ & $-0.212 *$ & $0.419 * *$ & $0.753 * *$ & & & & & & \\
\hline & $r_{p}$ & $0.558 * *$ & $0.543 * *$ & -0.044 & $0.368 * *$ & $0.720 * *$ & & & & & & \\
\hline \multirow{2}{*}{$\begin{array}{l}\text { Cob length } \\
\quad(\mathrm{cm})\end{array}$} & $r_{g}$ & $-0.232 *$ & $-0.225^{*}$ & 0.094 & $-0.282 * *$ & $-0.247 *$ & $-0.272 * *$ & & & & & \\
\hline & $r_{p}$ & -0.200 & -0.182 & 0.052 & $-0.255^{*}$ & -0.192 & -0.193 & & & & & \\
\hline \multirow{2}{*}{$\begin{array}{l}\text { Cob diameter } \\
\text { (cm) }\end{array}$} & $r_{g}$ & 0.003 & -0.013 & -0.120 & $-0.271 * *$ & $0.355^{* *}$ & $0.210 *$ & -0.012 & & & & \\
\hline & $r_{p}$ & -0.049 & -0.027 & 0.064 & -0.193 & $0.284 * *$ & 0.161 & 0.036 & & & & \\
\hline \multirow{2}{*}{$\begin{array}{l}\text { No. of grain } \\
\text { rows/ cob }\end{array}$} & $r_{g}$ & $-0.461 * *$ & $-0.431 * *$ & $0.294 * *$ & $-0.472 * *$ & $-0.247 *$ & $-0.362 * *$ & $0.416 * *$ & $0.351 * *$ & & & \\
\hline & $r_{p}$ & $-0.380 * *$ & $-0.322 * *$ & 0.171 & $-0.371 * *$ & $-0.234^{*}$ & $-0.344 * *$ & $0.347 * *$ & $0.367 * *$ & & & \\
\hline \multirow{2}{*}{$\begin{array}{c}\text { No. of } \\
\text { grains/row }\end{array}$} & $r_{g}$ & $0.501 * *$ & $0.475 * *$ & $-0.272 * *$ & $0.292 * *$ & $0.752 * *$ & $0.711 * *$ & $-0.218^{*}$ & $0.521 * *$ & 0.007 & & \\
\hline & $r_{p}$ & $0.395 * *$ & $0.360 * *$ & -0.103 & $0.218 *$ & $0.658 * *$ & $0.637 * *$ & -0.059 & $0.436 * *$ & 0.040 & & \\
\hline \multirow{2}{*}{$\begin{array}{l}\text { 100-Seed } \\
\text { weight }(g)\end{array}$} & $r_{g}$ & $0.210 *$ & $0.240 *$ & 0.180 & 0.080 & $0.631 * *$ & $0.524 * *$ & $-0.237 *$ & $0.300 * *$ & $-0.267 *$ & $0.451 * *$ & \\
\hline & $r_{p}$ & 0.130 & 0.155 & 0.074 & 0.029 & $0.576 * *$ & $0.487 * *$ & -0.110 & $0.320 * *$ & $-0.232 *$ & $0.437 * *$ & \\
\hline \multirow{2}{*}{$\begin{array}{c}\text { Grain yield/ } \\
\text { plant (g) }\end{array}$} & $r_{g}$ & -0.018 & -0.061 & $-0.305 * *$ & -0.185 & $0.642 * *$ & $0.451 * *$ & -0.196 & $0.620 * *$ & $0.254 *$ & $0.686^{* *}$ & $0.469 * *$ \\
\hline & $r_{p}$ & -0.023 & -0.040 & -0.052 & -0.144 & $0.558 * *$ & $0.395 * *$ & -0.061 & $0.574 * *$ & $0.272^{* *}$ & $0.701 * *$ & $0.459 * *$ \\
\hline
\end{tabular}

* Significant at $5 \%$ level ${ }^{* *}$ Significant at $1 \%$ level 
Table.2 Genotypic (Pg) path-coefficient analysis showing direct and indirect effects of different traits on grain yield per plant

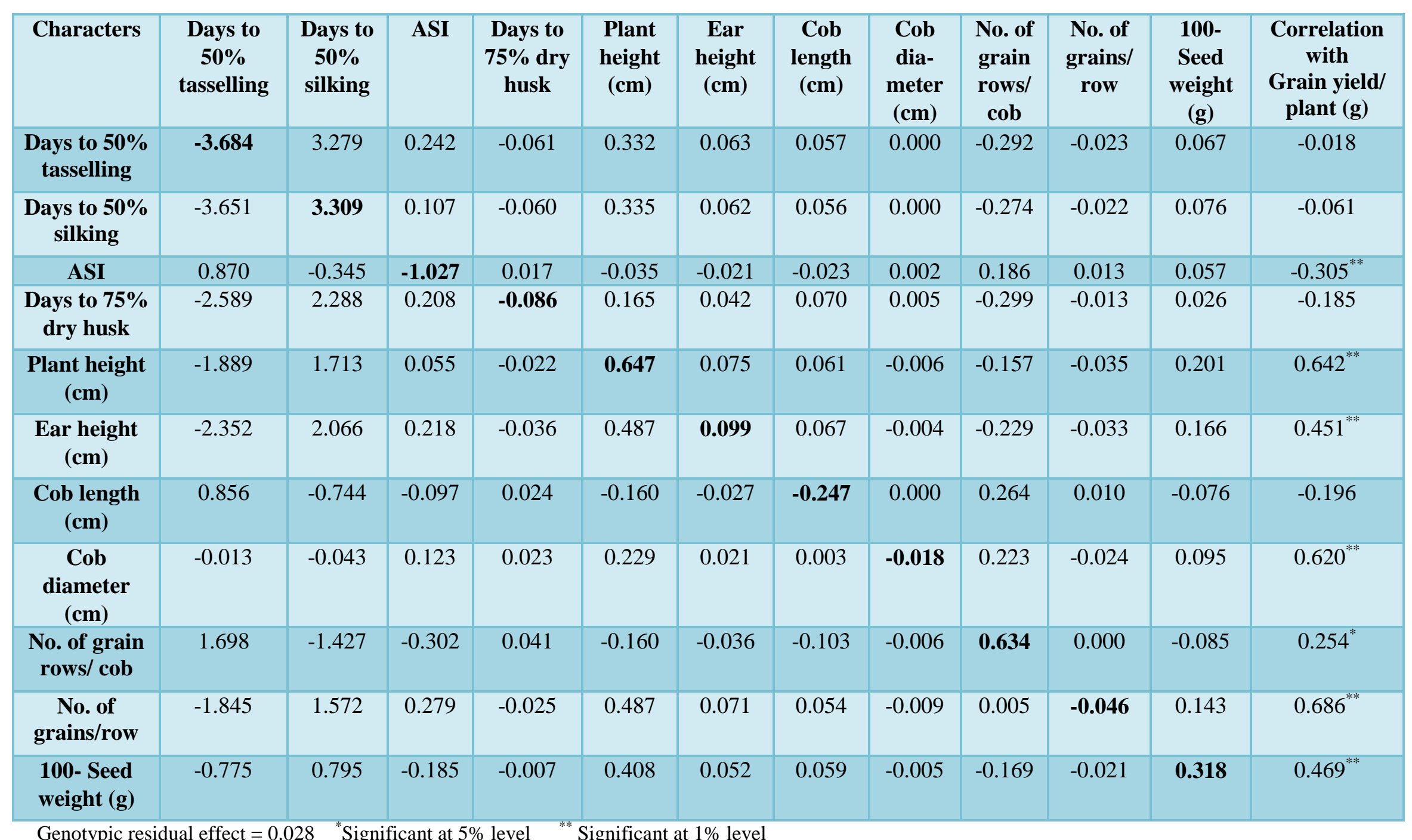


Correlation analysis is not sufficient to explain the true association as it does not indicate the cause and effect relationship, hence the correlated traits have to be further analysed to determine the direct and indirect effects of individual yield components on grain yield per plant through path analysis.

According to Pavan et al., (2011), traits having high positive correlation along with high direct effects are expected to be useful as selection criteria in improvement program. The residual effect of 0.028 indicated that the studied characters were almost sufficient to determine the dependent variable i.e. grain yield per plant in maize under heat stress condition. Days to $50 \%$ tasselling exhibited highest negative direct effect, whereas days to $50 \%$ silking recorded highest positive direct effect among all the traits under study. Both the traits were complementing each other as days to $50 \%$ silking contributed highest positive indirect effect on days to $50 \%$ tasselling while days to $50 \%$ tasselling put highest indirect effect on days to $50 \%$ silking. Therefore, these two traits nullified their effects with each other leading to a nonsignificant correlation with yield per plant. Such finding was earlier reported by Omprakash et al., (2017).

The characters; plant height, number of grain rows per cob and 100 seed weight exhibiting high positive direct effect on grain yield per plant were also reported with high positive correlation with the same. Hence, selection for these component traits could be considered as important criteria in improving grain yield per plant in maize under heat stress condition. These results are mostly in accordance with the earlier findings of Azhar et al., (2016), Dinesh et al., (2016a), Khodarahmpour and Choukan, (2011), Pavan et al., (2011) and Begu et al., (2016). It is worth to note that cob diameter and number of grains per row recorded negative direct effect, but positive correlation with grain yield per plant. The positive correlation might arise due to high positive indirect effects via plant height. Thus in maize hybrids, tall stature was associated with better yield and might be taken into consideration for further studies under heat stress. This finding is in accordance with Al-Tabbal and Al-Fraihat (2012). Ear height possessed very less positive direct effect but significantly high positive correlation with grain yield per plant. This result is supported by Khodarahmpour (2012), who suggested that tall plants with high ear placement gave better yield under heat stress. Anthesis to silking interval is the only character that exhibited negative correlation and also negative direct effect on grain yield per plant. Such finding was also reported by Magorokosho et al., (2003). Hence, for improving grain yield, emphasis must be given for selecting genotypes with minimum anthesis to silking interval.

The results obtained from this research of character association and path coefficient analysis revealed that plant height, ear height, number of rows per cob, and 100 seed weight in positive direction and anthesis to silking interval in negative direction have significant influence on grain yield per plant in maize under heat stress condition. Thus selection for these characters can be considered as important criteria in improving grain yield of maize under heat stress.

\section{References}

Alake, C. O., Ojo, D. K., Oduwaye, O. A. and Adekoya, M. A. 2008. Genetic variability and correlation studies in yield and yield related characters of tropical maize (Zea Mays L.). Asset Series A., 8(1): 14-27.

Al-Tabbal, J. A. and Al-Fraihat, A. H. 2012. Genetic variation, heritability, phenotypic and genotypic correlation 
studies for yield and yield components in promising barley genotypes. J. Agric. Sci.,4: 193.

Alvi, M. B., Rafique, M., Tariq, M. S., Hussain, A., Mahmood, T., Sarwar, M. 2003. Character association and path coefficient analysis of grain yield and yield components maize (Zea mays L.). Pak J. Biol. Sci., 6(2): 136-138.

Azhar, F. M., Ali, Z., Akhtar, M. M., Khan, A. A., and Trethowan, R. 2009. Genetic variability of heat tolerance, and its effect on yield and fiber quality traits in upland cotton (Gossypium hirsutum L.). Plant Breed., 128: 356-362.

Begum, S., Ahmed, A., Omy, S. H., Rohman M. M. and Amiruzzaman M. 2016: Genetic variability, character association and path analysis in maize (Zea mays L.) Bangladesh J. Agril. Res., 41(1): 173-182

Cairns, J. E., Sonder, K., Zaidi, P. H., Verhulst, P. N., Mahuku, G., Babu, R., Nair, S. K., Das, B., Govaerts, B., Vinayan, M. T., Rashid, Z., Noor, J. J., Devi, P., Vicente, F. S. and Prasanna, B. M. 2012. Maize production in a changing climate: Impacts, adaptation, and mitigation strategies. Adv. Agron.,114: 1-65.

Deryng, D., Conway, D., Ramankutty, N., Price, J. and Warren, R. 2014. Global crop yield response to extreme heat stress under multiple climate changes.Environ. Res. Lett.9.

Dewey, D. R. and Lu, K. N. 1959. A correlation and path coefficient analysis of components of crested wheat grass seed production. Agron. J.,51: 515-518.

Dinesh,A., Patilm, A., Zaidi, P. H., Kuchanur, P. H., Vinayan, M. T., Seetharam K. and Ameragouda. 2016a.Dissection of heat tolerance mechanism in tropical maize. Res. Crop., 17(3): 462-467.

FAOSTAT. 2017. Food and Agricultural Organization of the United Nations
(FAO): FAO Statistical Database, from http://faostat.fao.org.

Ghosh, A., Subba, V., Roy A., Ghosh A. and Kundagrami S., 2014. Genetic variability and character association of grain yield components in some inbred lines of maize (Zea mays L.). J. Agroecol. Nat. Reso. Man. 1(2): 34-39

IPCC (2009). Fifth Assessment Report : Synthesis. Published online 18 December 2009.

Jodage, K., Kuchanur, P. H., Zaidi, P. H., Patil, A., Seetharam, K., Vinayan, M. T., Arunkumar, B. 2017. Association and path analysis for grain yield and its attributing traits under heat stress condition in tropical maize (Zea mays L.). Electron. J. Plant Breed., 8(1): 336341.

Khazaei, F., Alikhani, M. A., Yari, L., Khandan, A. 2010. Study the correlation, regression and path coefficient analysis in sweet corn (Zea mays var. saccharata) under different levels of plant density and nitrogen rate. ARPN J. Agric. Biol. Sci., 5(6): 14-19.

Khodarahmpour, Z. 2012. Morphological classification of maize (Zea mays L.) genotypes in heat stress condition. J. Agric. Sci., 4: 1-14.

Khodarahmpour, Z. and Choukan, R. 2011. Study of the genetic variation of maize (Zea mays L.) inbred lines in heat stress condition using cluster analysis. Seed and Plant Improve. J. 27: 539-54.

Lobell, D. B., Schlenker, W. S. and CostaRoberts, J. 2011. Climate trends and global crop production since 1980 . Sci., 333: 616-20.

Magorokosho, C., Pixley, K. V. and Tongoona, P. 2003. Selecting for drought tolerance in two tropical maize populations. Afr. Crop Sci. J., 11: 15161.

Magorokosho, C., Pixley, K. V. and Tongoona, P., 2003. Selecting for 
drought tolerance in two tropical maize populations. Afr. Crop Sci. J., 11: 15161.

Najeeb, S., Rather, A. G., Parray, G. A., Sheikh, F. A., Razvi, S. M. 2009. Studies on genetic variability, genotypic correlation and path coefficient analysis in maize under high altitude temperate ecology of Kashmir. Maize Genetics Cooperation Newsletter, 83: 1-8.

Nemati, A., Sedghi, M., Sharifi, R. S., Seiedi, M. N. 2009. Investigation of correlation between traits and path analysis of corn (Zea mays L.) grain yield at the climate of Ardabil region (Northwest Iran). Not. Bot. Horti Agrobo., 37(1): 194-198.

Palta, C., Karadavut, U., Tezel, M., Aksoyak, S. 2011. Agronomic performance of some corn cultivars (Zea maize L.) in middle Anatolia. J. Anim. Vet. Adv.,10(14): 1901-1905.

Pavan R., Lohithaswa, H. C., Wali, M. C., Prakash G. and Shekara. B. G., 2011. Correlation and path coefficient analysis of grain yield and yield contributing traits in single cross hybrids of maize (Zea mays L.). Electronic J. Pl. Breed. 2(2):253-257.

Rafiq, C. M., Rafiqu, M., Hussain, A. and Altaf, M., 2010.Studies on heritability, correlation and path analysis in maize
(Zea mays L.). J. Agric. Res., 48(1): 3538.

Rowhani, P., Lobell, D. B., Linderman, M. and Ramankutty, N., 2011. Climate variability and crop production in Tanzania. Agr. Forest Meteorol., 151: 449-60.

Singh, O., Chourasia, K. N., Gobu, R. and Jakhar D. S., 2017. Character association and path coefficient studies for grain yield and related yield attributes among maize inbreds. Int. J. Adv. Biol. Res., 7 (1): 91-95.

Usha Rani, G., Rao V. S., Ahmad M. L., and Narasimha Rao K. L., 2017. Character association and path coefficient analysis of grain yield and yield components in maize (Zea mays L.). Int. J. Curr. Microbiol. App. Sci., 6(12): 4044-4050.

Wahid, A., Gelani, S., Ashraf, M. and Foolad, M. R., 2007. Heat tolerance in plants: An overview. Environ. Exp. Bot.,61: 199-223.

Wali, M. C., Kachapur, R. M., Kulkarni, V. R. and Hallikeri, S. S., 2012. Association studies on yield related traits in maize (Zea mays L.). Maize Journal, 1(2): 131-133

Wright, S., 1921. Correlation and causation. J.Agric. Res., 20: 557-85.

\section{How to cite this article:}

Asit Prasad Dash, D. Lenka, S. K. Tripathy, D. Swain and Devidutta Lenka. 2020. Character Association and Path Analysis of Grain Yield and its Components in Maize (Zea mays L.) under Heat Stress. Int.J.Curr.Microbiol.App.Sci. 9(03): 2750-2758.

doi: https://doi.org/10.20546/ijcmas.2020.903.315 